Arch. Mikrobiol. 66, 129-146 (1969)

\title{
Zoosporic Marine Fungi from the Pacific Northwest (U.S.A.)
}

\author{
Frederick K. SparRow* \\ Friday Harbor Laboratories, University of Washington and \\ Department of Botany, University of Michigan, Ann Arbor, Michigan
}

Received February 2, 1969

Summary. An investigation of the zoosporic fungi in the vicinity of the Friday Harbor Laboratory, San Juan Is., Washington, revealed the presence of great numbers of fungi. With one exception (Olpidium sp.) these were all biflagellate organisms. Predominating were species (11) of Thraustochytriaceae which abounded in water, in association with seaweeds, intertidal sands, and particularly on the surface of bottom samples down to depths of $298 \mathrm{~m}$. A twelfth species of this group has several peculiarities and needs further investigation. Of the algal parasites, one on Polysiphonia and Pterosiphonia is considered new and termed Eurychasma joycei n. sp.

Aside from the few fungi noted in JoHnson (1966), and Fuller et al. (1964), little is known of the zoosporic marine Phycomycetes from the Pacific Northwest coast. The observations herein reported were made during a 10-week stay at the Friday Harbor Laboratory, University of Washington, San Juan Island in the summer of 1968.

It is of interest to note that only one of the zoosporic fungi found belonged to the Chytridiomycetes, i.e., those with a single posterior flagellum on their zoospore, which are so abundant in fresh water. The others were all biflagellate forms belonging primarily to the Saprolegniales. This peculiarity had previously been noted among marine Phycomycetes from the Atlantic coast of the United States and in the Carribean area (SPaRrow, 1936, 1968).

\section{Methods}

Algal parasites were found by direct examination of the hosts. Saprophytes such as the Thraustochytriaceae were obtained by baiting with pine pollen debris, bottom mud or water from the various sites. Pure cultures on solid media were obtained by use of Vishniac's agar to which had been added antibiotics (FULLeR et al., loc. cit.).

* The assistance of Drs. R. E. NorRIS and G. J. Hollenberg in calling my attention to certain algal parasites is gratefully acknowledged. I am also indebted to my colleague Dr. H. C. WhisLer, and to Dr. C. ANastastou for assistance in photographic work. 


\section{Fungi Collected}

\section{A. Thraustochytriaceae}

\section{Occurrence}

The Thraustochytriaceae were the most widespread and numerous of all the fungi collected.

They were recovered from virtually every site examined. Bits of non-planktonic algae and marine angiosperm drift cast up on the shore always yielded them as did the sands between tide levels and bottom samples of mud at all depths explored. They were also associated with seaweeds dredged up from the bottoms at various depths and sites in the straits around San Juan Island and could nearly always be demonstrated in water samples of sufficient quantity within which their propagules were evidently suspended.

Although Thraustochytrium proliferum Sparrow, the type of the genus, was originally described as a saprophyte on dead or moribund macroscopic algae and was occasionally so found around San Juan Isle, as well as on diatoms, there has been evidence (VISHNIAC, 1956; FuLLER, et $a l ., 1964)$ to show that the relationship of the two organisms, fungus and alga, need not always be an intimate one and that, in fact, fungus propagules may be merely adhering to the algal surface.

Table. Summary of Thraustochytriaceae obtained from various bottom sites around San Juan Island ${ }^{1}$

\begin{tabular}{|c|c|c|c|c|}
\hline Locality & Date & Depth & Sample & Fungi \\
\hline Griffin Bay & 6.20 & $70 \mathrm{~m}$ & grab & $1,2,5,9,11$ \\
\hline Griffin Bay & 8.12 & $15 \mathrm{~m}$ & $\begin{array}{l}\text { bottom water } \\
\text { surface mud }\end{array}$ & $\begin{array}{l}11 \\
3,5,6,11\end{array}$ \\
\hline Orcas Is. East Sound & 7.2 & $34 \mathrm{~m}$ & grab & $1,4,5,8,11$ \\
\hline East Sound & 8.6 & $31 \mathrm{~m}$ & $\begin{array}{l}\text { bottom water } \\
\text { surface mud }\end{array}$ & $\begin{array}{l}4,5 \\
4,6\end{array}$ \\
\hline East Sound & 8.6 & $26 \mathrm{~m}$ & $\begin{array}{l}\text { bottom water } \\
\text { surface mud }\end{array}$ & $\begin{array}{l}6 \\
7 \\
\end{array}$ \\
\hline Orcas Is. West Sound & 8.6 & $34 \mathrm{~m}$ & surface mud & $4,5,6$ \\
\hline Harney $^{2}$ Channel & 8.6 & $80 \mathrm{~m}$ & $\begin{array}{l}\text { bottom water } \\
\text { Slurry } \\
\text { surface mud } \\
6 \mathrm{~cm} \text { core } \\
12 \mathrm{~cm} \text { core } \\
\end{array}$ & $\begin{array}{l}1,6,7,11 \\
1,5,7 \\
5,7 \\
- \\
-\end{array}$ \\
\hline $\begin{array}{l}\text { Orcas Is. Between } \\
\text { Salmon Bite } \\
\text { and Flat Top }\end{array}$ & 7.29 & $174 \mathrm{~m}$ & $\begin{array}{l}\text { bottom water } \\
\text { surface mud } \\
13 \mathrm{~cm} \text { core } \\
27 \mathrm{~cm} \text { core }\end{array}$ & $\begin{array}{l}1,6 \\
5,6,11 \\
- \\
-\end{array}$ \\
\hline$\overline{\text { Waldron Is. }}$ & 7.29 & $34 \mathrm{~m}$ & grab & $4,5,8,11$ \\
\hline
\end{tabular}


Table (Continued)

\begin{tabular}{|c|c|c|c|c|}
\hline Locality & Date & Depth & Sample & Fungi \\
\hline Lopez Is. Flat Pt. & 8.6 & $68 \mathrm{~m}$ & grab & $1,4,5,11$ \\
\hline Spieden Channel & 7.18 & $202 \mathrm{~m}$ & $\begin{array}{l}\text { bottom water } \\
\text { surface mud }\end{array}$ & $\begin{array}{l}4 \\
4,5,6\end{array}$ \\
\hline $\begin{array}{l}\text { Haro Strait off } \\
\text { Deadman's Bay }\end{array}$ & 7.18 & $270 \mathrm{~m}$ & $\begin{array}{l}\text { bottom water } \\
\text { and slurry } \\
\text { surface mud } \\
11 \mathrm{~cm} \text { core }\end{array}$ & $\begin{array}{l}2 \\
1,4,6,11 \\
-\end{array}$ \\
\hline $\begin{array}{l}\text { Haro Strait off } \\
\text { Deadman's Bay }\end{array}$ & 8.18 & $294 \mathrm{~m}$ & $\begin{array}{l}\text { (fragmented core) } \\
\text { slurry only }\end{array}$ & $\begin{array}{l}\text { Thrausto- } \\
\text { chytrium spp. } \\
\mathbf{1 1}\end{array}$ \\
\hline $\begin{array}{l}\text { Haro Strait off } \\
\text { Deadman's Bay }\end{array}$ & 8.18 & $296 \mathrm{~m}$ & slurry only & $\begin{array}{l}\text { Thrausto- } \\
\text { chytrium. }\end{array}$ \\
\hline $\begin{array}{l}\text { Haro Strait off } \\
\text { Deadman's Bay }\end{array}$ & 8.18 & $298 \mathrm{~m}$ & $\begin{array}{l}\text { bottom water } \\
\text { surface mud } \\
3 \mathrm{~cm} \text { core } \\
7 \mathrm{~cm} \text { core } \\
13 \mathrm{~cm} \text { core }\end{array}$ & $\begin{array}{l}\text { Thrausto- } \\
\text { chytrium sp. } \\
\text { - } \\
\text { Thrausto- } \\
\text { chytrium sp. } \\
\text { - } \\
\text { - }\end{array}$ \\
\hline $\begin{array}{l}\text { Juan de Fuca Strait } \\
\text { Salmon Bank }\end{array}$ & 7.18 & $16 \mathrm{~m}$ & grab & $1,4,9(?)$ \\
\hline \multicolumn{5}{|c|}{$\begin{array}{l}{ }^{1} \text { Following numbers are used to designate the various fungi in the table } \\
1=T . \text { proliferum, } 2=T . \text { aureum, } 3=T . \text { motivum, } 4=T \text {. multirudimentale } \\
5=T . \text { aggregatum, } 6=T . \text { globosum, } 7=T . \text { pachydermum, } 8=T \text {. rosenm, } 9=T \\
\text { visurgense, } 10=T . \text { striatum, } 11=\text { Schizochytrium aggregatum. } \\
\quad 2 \text { Data by PAUL RING. }\end{array}$} \\
\hline
\end{tabular}

By the following simple test, it was clearly demonstrated that such was true and that in this association a natural organic substratum need not, in fact, be involved. Nine short plastic rods were submerged from the dock of the Friday Harbor laboratory for a period of 6 weeks. These were then recovered, thoroughly washed several times in sterile sea water and implanted on the aforementioned modified Vishniac antibiotic media. Six of the nine rods produced outgrowths of Thraustochytrium (T. roseum) as well as of several Fungi Imperfecti.

Bottom mud was the most prolific source of Thraustochytrium and tidal flats, such as that opposite Turn Rock, Friday Harbor, appeared to have a great numbers of them, primarily $T$. roseum.

By means of a Pfleger bottom sampler and samples obtained with a Petersen grab, considerable was learned as to occurrence in bottom mud of Thraustochytrium at off-shore sites at different depths. The preceding Table summarizes these data.

As may be seen, fungi were obtained at all sites, either in bottom water, shurry, or mud samples, or cores, down to $298 \mathrm{~m}$. Just why none 
was found on the surface of the core off Deadman's Bay $298 \mathrm{~m}$ August 18, but appeared at $3 \mathrm{~cm}$ depth in the core is hard to explain except as a result of faulty manipulation of the core. Owing to the lightness of the sampler, difficulty was experienced working at depths of approximately $300 \mathrm{~m}$ due to prevailing strong tidal currents.

\section{Quantitative Data}

It seemed evident from the rapidity of development (48 hours), numbers, and variety of Thraustochytriaceae, that they were a most important component of the marine fungous flora. Attempts were then made to estimate the numbers of propagules present in water by the MPN-pollen grain method outlined by GAERTNER (1968) and used with great success by him in the North Sea and by SchNeIDer (1968) in the West- and Mid-Baltic. Two series were run from water samples collected at outgoing low tide off the Friday Harbor Laboratory dock. One, set up July 10, gave a figure of 750 per liter, whereas another set up August 5 yielded 1072 per liter.

Attempts to estimate density of propagules in mud samples by use of MPN-pollen grain method of GAERTNeR (1968) and by ordinary dilutions were not entirely satisfactory. This was due primarily to lack of time to process a sufficient number of cores and to evaluate methods

used. Data collected by Mr. PAUL RING by the MPN-pollen method on a core approximately $14 \mathrm{~cm}$ long from the bottom of East Sound, Orcas Ts. in $26 \mathrm{~m}$ of water from surface of sample and from $7 \mathrm{~cm}$ depth gave figures of $9 \mathrm{mil} / \mathrm{L} \mathrm{mud}$, and $687,500 / \mathrm{L} \mathrm{mud}$, respectively. A replicate of each confirmed this ratio of approximately 15:1, surface, compared with $7 \mathrm{~cm}$ depth. These numbers are considerably larger than those reported by GAERTNER (1968) and should unquestionably be evaluated with caution. The data were, however, reasonably consistent in emphasizing that Thraustochytriaceae were primarily inhabitants of the surface layer, but not confined to that stratum. A variety of species was obtained. The near absence of $T$. roseum, so ubiquitous an inhabitant of tidal flats, water, intertidal sands, etc., was, however, noteworthy.

\section{Thraustochytrium proliferum Sparrow}

Bottom mud, Griffin Bay, $70 \mathrm{~m}$ (dominant), 6.20; dead diatom, Salmon Bank, $16 \mathrm{~m}, 6.20,7.18$; $34 \mathrm{~m}$, East Bay, Oreas Is., 7.2; dead Bryopsis, Friday Harbor, 7.5; algal drift, Friday Harbor, 7.6; surface mud, $270 \mathrm{~m}$, Haro Strait, 7.18; bottom water, $174 \mathrm{~m}$, off Orcas Is. between Salmon Bite and Flat Top; surface mud, $68 \mathrm{~m}$, Flat Point off Lopez Is., 8.6.

This species (Fig. 1) occurs primarily in bottom muds in deep water. It was occasionally found on dead intertidal diatoms. 


\section{Thraustochytrium pachydermum Scholz}

Salt pond, surrounded by Salicornia, off beach, north of American Camp, (dominant), 7.17; surface mud, $26 \mathrm{~m}$, East Sound, Orcas Is. 8.6.

Almost the sole species found in the highly saline water and in the salt-caked soil of the beach pool.

\section{Thraustochytrium globosum Kobayashi and Ookubo}

Surface mud, $202 \mathrm{~m}$, Spieden Channel, 7.18; bottom water, $174 \mathrm{~m}$, off Orcas Is., between Salmon Bite and Flat Top; bottom water, $26 \mathrm{~m}$, surface mud, $31 \mathrm{~m}$, East Sound, Orcas Is., 8.6; surface mud, $34 \mathrm{~m}$ West Sound, Orcas Is. 8.6; intertidal sand, South Beach, San Juan Is., 8.11; surface mud, $15 \mathrm{~m}$, Griffin Bay, 8.12; surface mud, $270 \mathrm{~m}$, Haro Strait, 7.18.

A common species (Figs.5 and 6) in the area. The basal part of sporangium was usually persistent for some time after discharge.

\section{Thraustochytrium motivum Goldstein}

Surface mud and slurry, $34 \mathrm{~m}$, East Sound, Orcas Is., 7.2 ; surface mud, $15 \mathrm{~m}$, Griffin Bay, 8.12.

Such a fungus as shown in Fig. 2 was obtained from many sites. In only a few, however, could zoospore production be induced (Figs. 3 and 4) and the identity established.

\section{Thraustochytrium aureum Goldstein}

Surface mud, $70 \mathrm{~m}$, Griffin Bay, 6.20; on dead naviculoid diatom, intertidal surface mud, opposite Turn Rock, Friday Harbor, 6.29; bottom water, $270 \mathrm{~m}$, off Deadman's Bay, 7.18.

The organisms depicted in Figs. 13 and 15 were only faintly pigmented. Whether Fig. 14 is this species is a question.

\section{Thraustochytrium multirudimentale Goldstein}

Surface mud, $34 \mathrm{~m}$, East Sound, Orcas Is., 7.2 (dominant); surface mud, $15 \mathrm{~m}$, Salmon Bank, 7.18; surface mud, $270 \mathrm{~m}$, Deadman's Bay, 7.18; bottom water $202 \mathrm{~m}$, Spieden Channel, 7.18 (dominant); surface mud, $34 \mathrm{~m}$, off Waldron Is., 7.29; bottom water and surface mud, $31 \mathrm{~m}$, East Sound Orcas Is., 8.6; surface mud, $34 \mathrm{~m}$, West Sound, Orcas Is., 8.6; surface mud, $68 \mathrm{~m}$, Flat Point, off Lopez Is., 8.6; intertidal sand, South Beach, San Juan Is., 8.11; associated with dredged algae, $16 \mathrm{~m}$, Salmon Bank, 6.20 .

The broad base of the sporangium and its several proliferating rudiments made this species easy to recognize (Figs. 7 and 8). Discharge (Fig.9) was only seen occasionally.

\section{Thraustochytrium aggregatum Ulken}

Associated with dredged algae, $16 \mathrm{~m}$, Salmon Bank, 6.20 ; surface mud, $34 \mathrm{~m}$, East Sound, Orcas Is., 7.2; surface mud, $202 \mathrm{~m}$, Spieden Channel, 7.18; surface mud, $34 \mathrm{~m}$, off Waldron Is., 7.29; bottom water, $31 \mathrm{~m}$, East Sound, Orcas Is., 

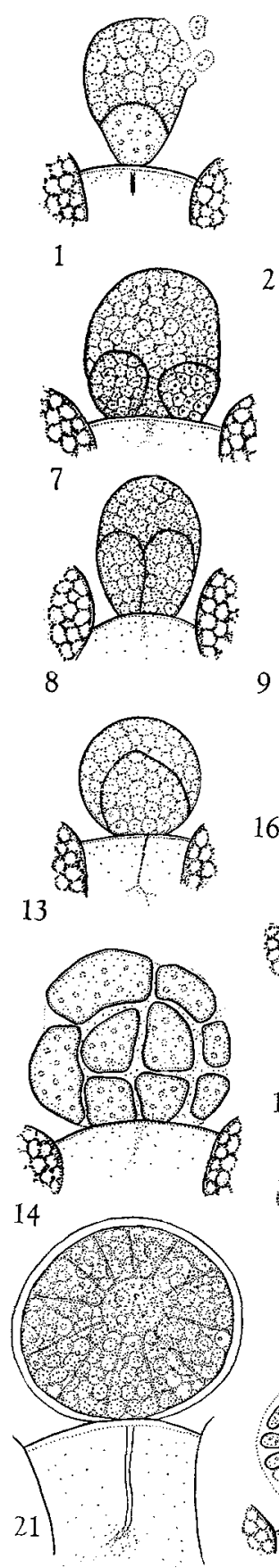
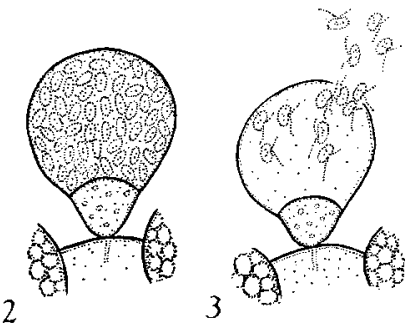

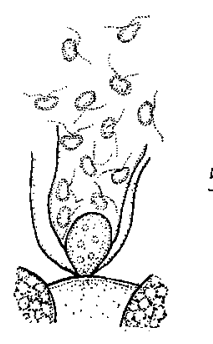

6

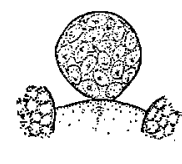

5

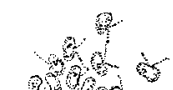

$\sqrt{4}$ 4

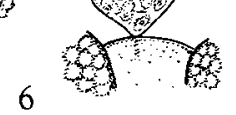

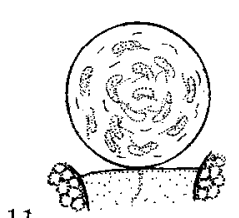

11
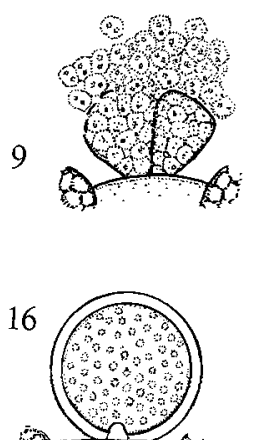

17

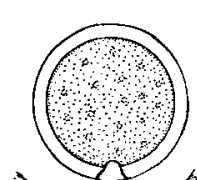

12

2

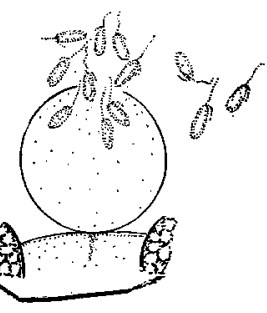

18

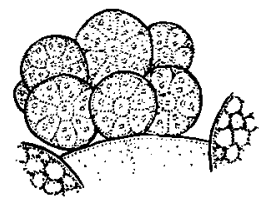

畕
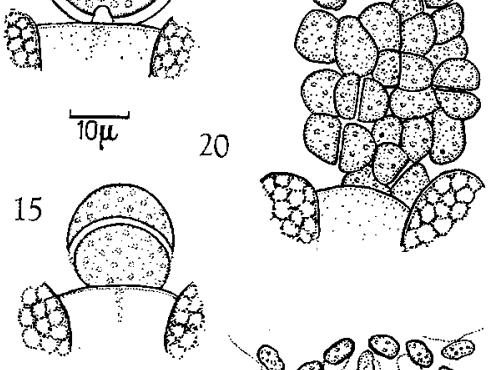

19

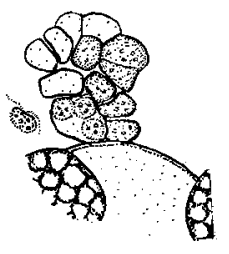

Q 900

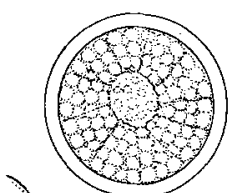

23

\% 19

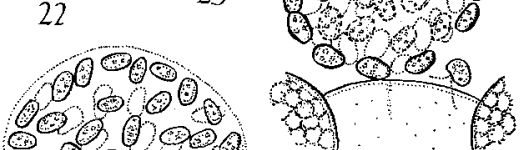

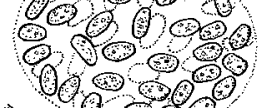

$100.0^{\circ}$

$\stackrel{ }{10 \mu}$

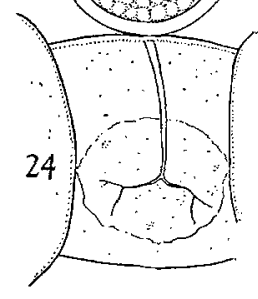

Figs. 1-24 
8.6; surface mud, $34 \mathrm{~m}$, West Sound, Orcas Is., 8.6 ; surface mud, $68 \mathrm{~m}$, off Flat Point, Lopez Is., 8.6.

Widespread in the area (Fig.18). The taxon is in need of further study, particularly to differentiate it from clusters of dwarf forms of other species.

\section{Thraustochytrium roseum Goldstein}

Associated with floating Zostera and sea weeds, Friday Harbor, 6.17; sand below low tide and intertidal, South Beach, San Juan Is., 6.30, and algal drift, 8.11; surface mud, $34 \mathrm{~m}$, East Sound, Orcas Is., 7.2; surface water and associated algal drift, Deadman's Bay, 7.6; intertidal beach sand, San Juan Park, San Juan Is., 7.6; intertidal mud, Garrison Bay, 7.10; surface water sample, Friday Harbor, 7.10; associated with plastic test rods, Friday Harbor, 8.12.

The brassy color is only detectable at low power. This species appears to be almost wholly confined to surface muds, water, and algal drift; not recovered from depths, except once

\section{Thraustochytrium visurgense Ulken}

Surface mud, 70 m, Griffin Bay, 6.20; surface mud, 16 m, Salmon Bank, 7.18; intertidal sand, South Beach, 8.11.

There was difficulty in distinguishing this species from the preceding one. The rhizoids are hard to see in both species and color in $T$. roseum is only detectable at lower powers of magnification and in culture media.

Figs.1-24. Various Thraustochytriaceae on pine pollen bait. Fig.1. Discharging sporangium of Thraustochytrium proliferum. Figs.2-4. T. motivum. Fig. 2. Mature sporangium. Fig. 3. Discharging sporangium. Fig.4. Twice proliferous sporangium discharging. At this stage distal part of sporangium wall begins to disappear. Figs.5-6. T. globosum. Fig. 5. Mature sporangium. Fig. 6. Discharge of zoospores. Figs. 7-9. T. multirudimentale. Figs. 7, 8. Mature sporangia with several rudiments. Spores of both sporangia and rudiments may be mature at same time. Fig. 9. Discharge of spores from both sporangium and rudiments. Figs. 10-12. Thraustochytrium sp. from bottom mud $298 \mathrm{~m}$. Figs. 10, 11. The narrow apparently anteriorly uniflagellate zoospores swimming violently within partially empty sporangia. Fig. 12. Discharge through an apical aperture. To right of sporangium are $3 \mathrm{zoo}-$ spores killed with iodine solution showing short, apically attached second flagellum. Figs. 13-15. T. aureum. Fig.13. Nearly mature sporangium showing proliferating rudiment. Fig.14. Surface view of cleaving cytoplasm of sporangium; possibly not this species. Fig.15. Young thallus with distal fertile and rudiment areas cleaved out. Figs. 16-17. T. visurgense. Two encapsulated sporangia with basal apophysis. Fig. 18. T. aggregatum. Cluster of maturing sporangia. Figs.19-20. Schizochytrium aggregatum. Fig. 19. Cluster of sporangia, one of which is discharging zoospores, others empty or immature. Fig. 20. Large cluster of sporangia. Absolute scale for Figs.1-20 beneath Fig. 16. Figs. 21-24. T. striatum from intertidal sand, Grand Bahama Is. Figs.21, 24. Nearly mature sporangia showing radial cleavage of cytoplasm. Fig. 22. Sporangium with large central vacuole and nearly mature zoospores. Fig. 23. Zoospores leaving hollow sphere of mature but motionless zoospores. Absolute scale Figs.21-24 beneath Fig. 23 
What is interpreted as this species is best exemplified by colorless material from South Beach Sand. Here, a well-defined apophysis is found (Figs.16 and 17), a structure clearly shown in ULKEx's photomicrographs (1965) but not mentioned in the species diagnosis.

\section{T. striatum Schneider (?)}

Beach sands, intertidal zone, South Beach, 8.11.

This recently described species (ScHNEIDER, 1968) was also found in intertidal zone coral sand at West Fnd, Grand Bahama Is., 1. 7.69 (Figs. 21-24). The radiate striations of the cytoplasm cited by Schneider as distinctive for this species (Figs.21 and 24) was noted in Thraustochytrium spp. from many more sites in the Friday Harbor area than the one cited above. They were usually considered merely phases of development, possibly of $T$. roseum. In the Bahamian material, however, observations on zoospore discharge confirmed ScHNEIDER's assertion that the discharging sporangium formed a conspicuous hollow sphere of zoospores (Figs.22 and 23). Unlike in his material, however, there was no activity of zoospores inside the sporangium. Rather, the sporangium wall deliquesced and the mass of motionless spores formed a hollow sphere. After a few minutes individual zoospores successively assumed motility and quitted the mass. The latter often broke up into clumps of spores which eventually left the mass as motile bodies. Another difference was found in the quiescent sporangium wall which in material both from Friday Harbor and the Bahamas (Figs.21 and 24) was distinctly thickened ("encapsulated"). Some of ScHNEIDER's figures also show such a wall, which like ours, seems to disappear at the hollow sphere stage of development. No pigmentation as in $T$. roseum was seen on pollen although such occurred in ScHNEIDER's material when grown on malt agar. Just how unvaried and significant the details of zoospore discharge are in various species needs further investigation. BooTh and Mruler (1968) have recently discussed this and other characters used in delineating species of Thraustochytrium. In the " $T$. roseum $-T$. visurgense complex" to which $T$. striatum belongs no significant variation in zoosporic discharge seems to be recorded.

\section{Schizochytrium aggregatum Goldstein}

Associated with floating Zostera, seaweeds, pier, Friday Harbor Laboratory, 6.17; surface water and bottom mud, $70 \mathrm{~m}$, Griffin Bay, 6.20; sand below low tide, and intertidal zone, South Beach, San Juan Is., 6.30; bottom slurry, $34 \mathrm{~m}$, East Sound, Orcas Is.,; surface water and algal drift, Deadman's Bay, 7.6 (dominant); beach sand, San Juan Park, San Juan Is.; surface mud, $34 \mathrm{~m}$, off Waldron Is., 7.29; bottom water, $80 \mathrm{~m}$, Harney Channel off Orcas Is., 8.16 ; surface mud, $270 \mathrm{~m}$, off Deadman's Bay, Haro Strait, 7.18. 
Schizochytrium aggregatum (Figs.19 and 20) from our observations appears to be one of the commonest of fungi in the area and occurs in surface water as well as in bottom mud. It was also found to be ubiquitous in the Carribean (SPARPow, 1968).

Other, partially observed Thraustochytriaceae need further study. A globose form recovered in slurry and botton mud from a core taken at $294-298 \mathrm{~m}$ off Deadman's Bay August 18 was remarkable in the structure of its zoospore. The sporangia (Figs. 10-12) were thin-walled, globose, $20-23 \mu$ in diameter. The rhizoidal system were it could be observed was delicate and unbranched. Zoospores often underwent a gradual accretion of individual motility within the sporangium which involved violent surging, then escaped through a distal poorly defined pore or cleft. The zoospore body was elongate, almost rod-like, $5 \times 2 \mu$, slightly tapering at both ends and bore a long median groove along the body. It possessed at first sight a single, strongly developed anterior flagellum as long or somewhat longer than the body. This flagellum undulated in its distal portion much as that of the members of the anteriorly uniflagellate Hyphochytriales. No other flagellum could be seen in the motile spore, particularly no trailing one, as might be expected in a thraustochytriaceous fungus. The movement was a steady forward progression interspersed with occasional changes of direction. When, however, zoospores were killed in iodine solution, there was revealed a second, much shorter flagellum which in the dead spore appeared attached at the same point as the forwardly-directed one but opposed to it. Either this short flagellum was posteriorly-directed and held close to the body or was parallel with and beat synchronously with the long anterior one. The anterior attachment of both flagella would suggest that we are dealing here with a primary zoospore as in Saprolegnia, and like species of that genus encystment would occur followed by emergence of a secondary zoospore. There is no evidence for this as yet.

\section{B. Ectrogellaceae}

\section{Ectrogella perforans Petersen}

On Fragilaria islandica (det. R. Norris), intertidal rocks, South Beach, San Juan Is. and Friday Harbor, 6.30.

At both sites up to 30 per cent of the cells of a filament were found to be infected. Such cells were noticeably expanded to $2-3$ times normal width (Figs.25-28). Many zoospores failed to escape through the $1-3$ short discharge tubes and encysted within the sporangium. Others escaped and came to rest in the vicinity of host.

On Licmophora sp. (Figs.29 and 30) from algae on walls of limestone quarry north of Limekiln Light, Haro Strait (coll. 7.26 by R. NoRRIS), 

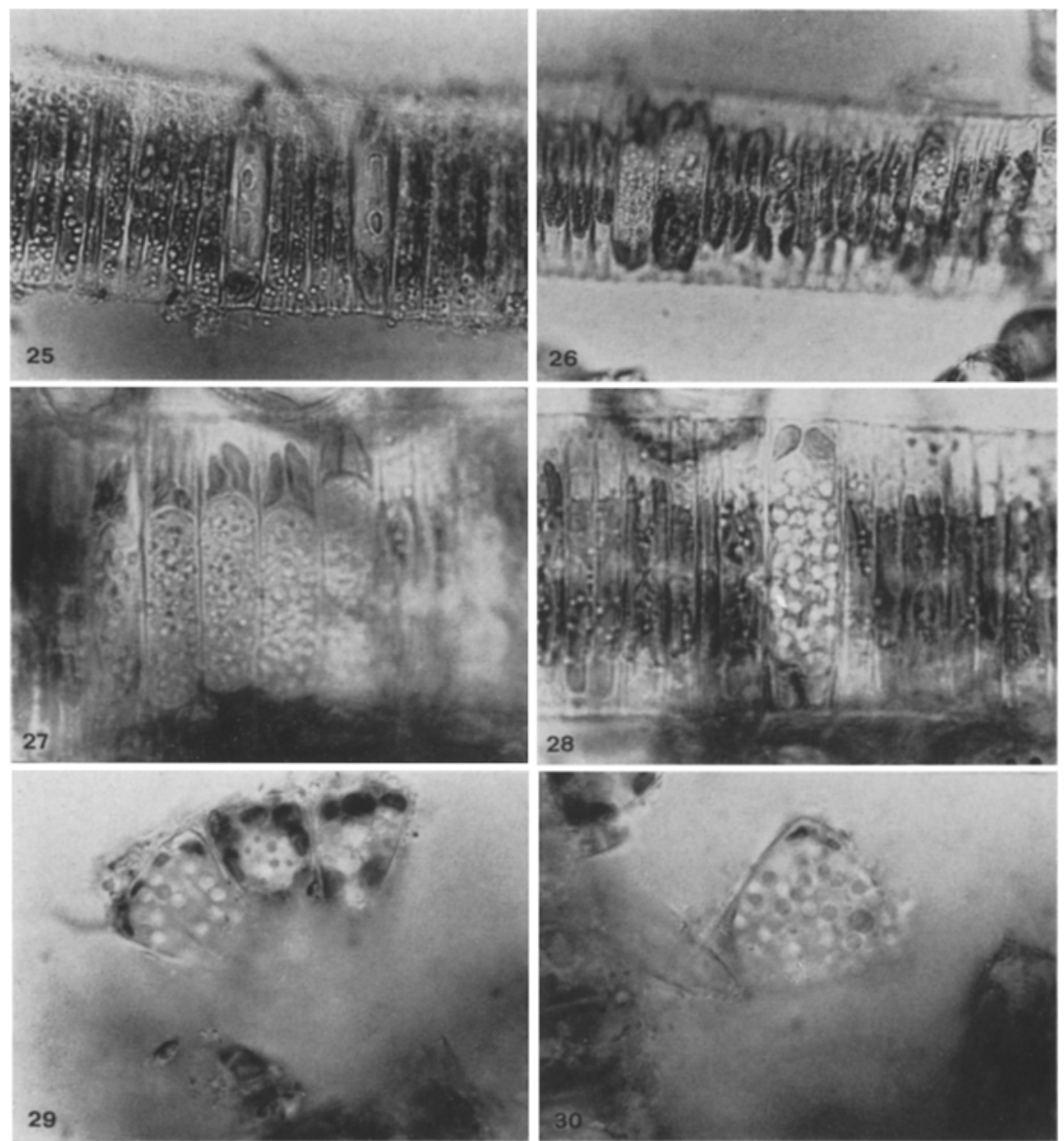

Figs. 25-30. Eetrogella perforans. Figs.25-28. In Fragilaria islandica. Fig. 25. Colony with two parasitized cells. The sporangia of the parasite have discharged through the several readily visible pores. Fig. 26. Colony showing 6 infected cells. Fig. 27. Portion of colony with heavy infection. The chromatophores are still reasonably intact. The left-most fungus has discharged some of its zoospores; some are still in the sporangium. Fig.28. Mature sporangium with zoospores ready to emerge. The enlarged condition of infected cell is evident when compared with adjacent uninfected ones. Figs. 29, 30. In Licmophora sp. Fig. 29. Three adjacent infected cells. Fig. 30. Mature sporangium with quiescent zoospores some of which have emerged from infected cell in process of mounting specimen (All photographs by C. Anastastiou) 
a 99 per cent infection of the diatom by the Ectrogella was observed. Many times populations of diatoms would be completely decimated save for 1-2 individuals. A greater degree of infection was found here than was recorded earlier from the East Coast (Sparrow, 1936). The epidemic persisted throughout the summer.

Two incompletely observed parasites, possibly referable to Ectrogella, were also found on diatoms. One, on Cocconeis sp. was from the aforementioned limestone quarry collection described above. Only broadly ellipsoid thalli (Figs. 35, 36) and empty sporangia, 8-10 $\times 14-15 \mu$, bearing a single discharge pore were seen (Figs. 37, 38). The other, a large one, in Hyalodiscus sp. from the same locality (Figs. 31-34) was fairly common. Data on the discharge and structure of the zoospores could not be obtained and hence its affinities are in doubt. The fungus thalli, of which there were 1-several in a host cell, were one-celled, saccate or most often lobulate, and very thin-walled (Fig. 31). The strap-like host chromatophores tended to shrink and collect around the fungus and partially obscure it. The only stages in sporulation seen were subsequent to liberation of the spores. At this time many quiescent small cysts about $4 \mu$ in diameter were scattered throughout the host cell (Figs. 32, 34). The wall of the sporangium had disappeared in most instances and only the configuration of the disintegrated brown chromatophore material outlined its boundary (Fig. 34). No discharge tubes were seen and it appeared virtually certain that the contents of the sporangium had been liberated by the deliquescence of its wall.

What is probably this same fungus was found in August 1962 by JoyCE GRIFFIN LongCORE off Battleship Is. perhaps in Coscinodiscus sp.

\section{Eurychasma spp.}

On ectocarpoid Phaeophyta, including Feldmannia simplex, limestone quarry north of Limekiln Light, (coll. R. Norris), 8.18.

A limited amount of infected material (Figs. 39-46) made interpretation of these fungi difficult. Indeed, it is not clear if we are dealing with one, or several different parasites. Certain infections were strikingly like Eurychasma dicksonii, which has been found a number of times on ectocarpoid algae. Thus, the strong hypertrophy of infected host cells (Fig. 41), the vacuolate stage ("stage écumeux") (Fig. 40) and the disposition of encysted zoospores within the sporangium around a huge central cavity (Figs. $42,43,46$ ) are reminiscent of $E$. dicksonii. It was noted, however, the last-named stage was contained within the host cell rather than being partially extramatrical.

What may be another fungus is seen in Figs. 39, 44. Here, a spherical or ellipsoidal very large thallus is borne loosely within a slightly enlarged host cell. Yet another possibly different parasite (Fig. 45) is borne 

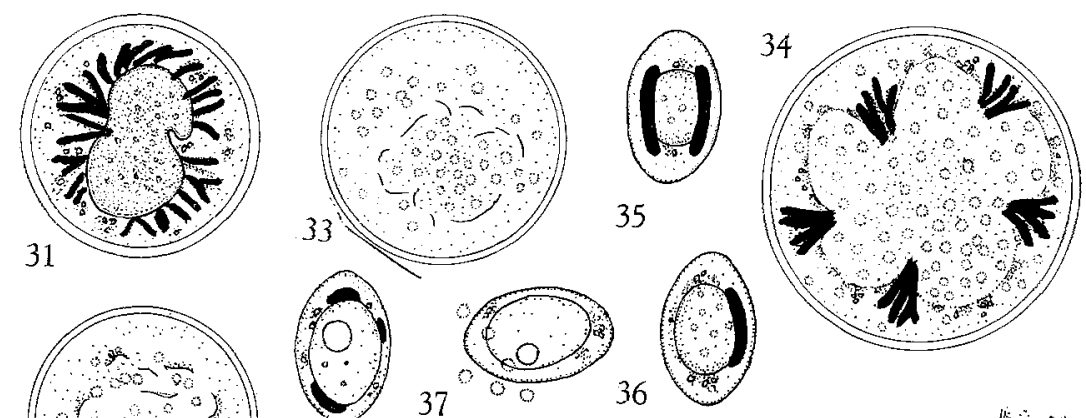

32
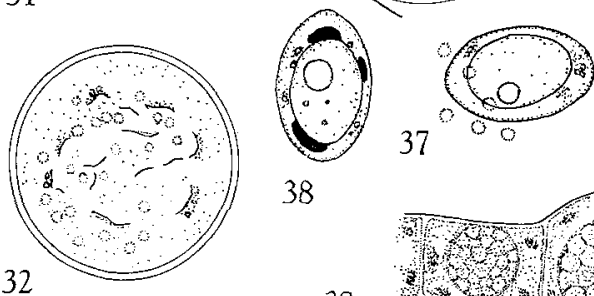

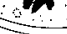

38 37

36

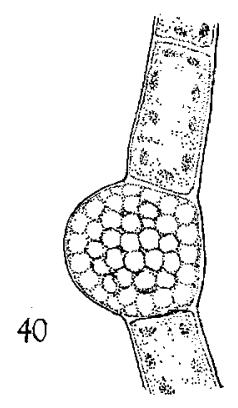

42

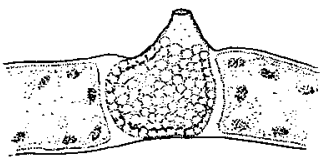

39
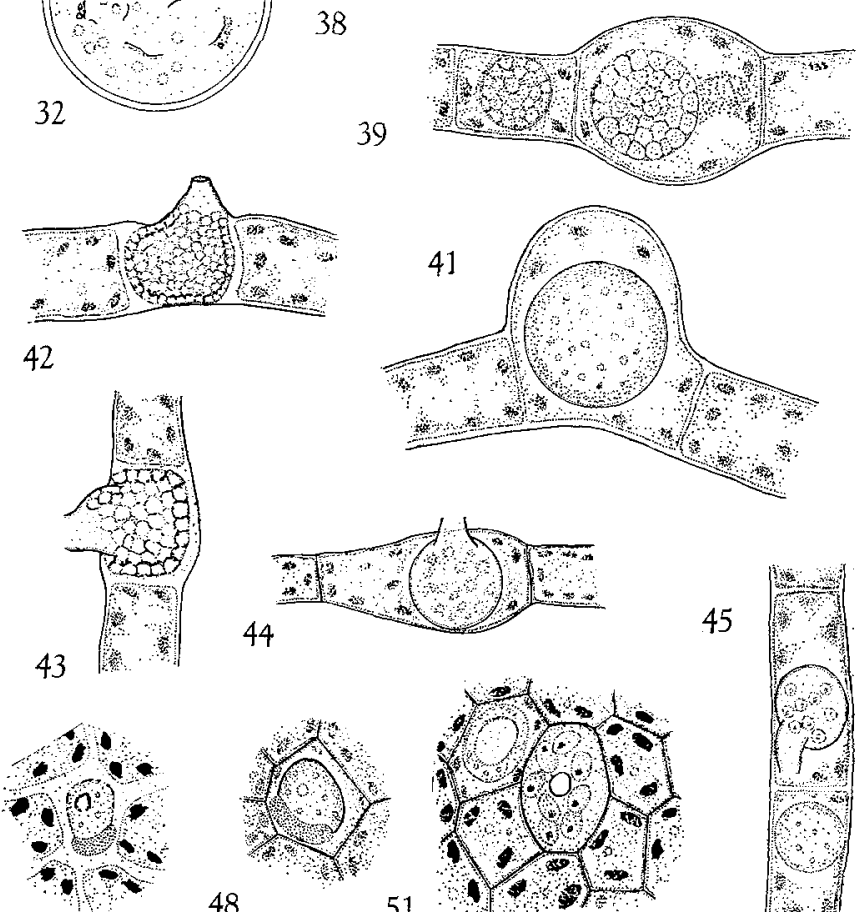

47

48
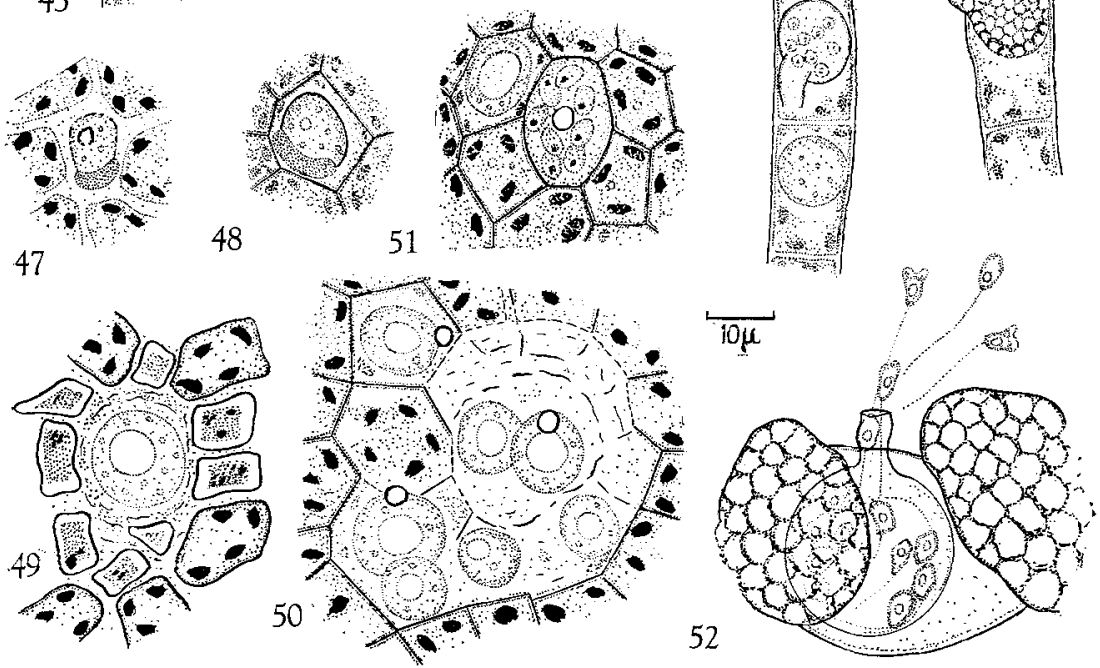

Figs. 31-52 
loosely within a nonhypertrophied host cell. Its sporangium has a more cylindrical discharge tube and the zoospores have been discharged save for a few which remain as $4-5 \mu$ in diameter loosely disposed cysts. Further observations will be necessary to delineate properly here what are probably several entities.

\section{Eurychasma sp.}

In Polysiphonia sp. and Pterosiphonia sp. Rocks at "Marvista" by False Bay, San Juan Is., 8.19 and 8.22, 1962 (coll. JoYce GrIfFin LongCORE); Polysiphonia sp., same site, 6.24, 1968 (coll. R. Norris); Polysiphonia, same site, 8.6, 1968 (coll. R. Norris and F. K. Sparrow).

Most of the critical observations on these fungi especially the zoospores were made by Mrs. Longcone and through her kindness are incorporated here.

Whether the fungi on the two hosts are identical is in need of further study. On Polysiphonia in the 1962 collection the fungus attacked only cells within 10 cells of the growing apex, and often the apical cell itself (Fig. 53). Such cells became distinctly swollen as the parasite, which remained wholly endobiotic, developed to maturity. Rarely, pericentral cells near the base of the plant were infected. Here, however, considerable extramatrical growth of the partially extruded fungus thallus took place (Fig. 55) as in the well-known Eurychasmia dicksonii on Brown Algae.

Fig.31-34. Parasite in Hyalodiscus sp. Fig. 31. Thallus in diatom cell; the chromatophores clustered around parasite. Figs. 32-34. Host cells in which the sporangium wall has all but disappeared (deliquesced?); numerous encysted zoospores throughout cells. In Fig. 34 a zone of disintegrated host contents outlines position of sporangium wall. Figs. 35-38. Parasite in Cocconeis sp. Figs. 35, 36. Immature thalli surrounded by reasonably intact host chromatophores. Figs. 37, 38. Empty parasite thalli each with large sessile discharge pore. Figs.39-46. Fungi (Eurychasma?) in various ectocarpoid Brown Algae. Fig.39. Two maturing thalli; larger has produced some hypertrophy of host. Fig.40. "Stage écumeux". Fig. 41. Strongly hypertrophied host with spherical thallus of a parasite. Figs.42, 43, 46. Open sporangia in cells of Feldmannia simplex; the quiescent spores surround a large central cavity. Figs. 44, 45. Parasite with spherical sporangium and nearly cylindrical discharge tube. Figs.47-51. Olpidiopsis sp. in Porphyra sp. Fig.47. Very young thallus with persistent cyst of infecting zoospore; the chromatophore is greenish. Fig. 48. More mature thallus. Note discoloration of chromatophores of surrounding cells. Fig. 49. Nearly mature thallus. Containing host cell wall has disintegrated, surrounding cells have chromatophores discolored and disintegrated. Fig. 50. A diseased area with some cysts of infecting zoospores still visible. Host cell walls in various stages of disintegration; chromatophores mostly discolored and disintegrated. This area will eventually drop out of the algal thallus and produce a "shothole". Fig. 51. Mature sporangium with discharge pore; a few biflagellate zoospores remain within. Fig.52. Olpidium $s p$. in pine pollen grain, discharging posteriorly uniflagellate zoospores. Absolute scale for all figures at upper left of Fig. 52 

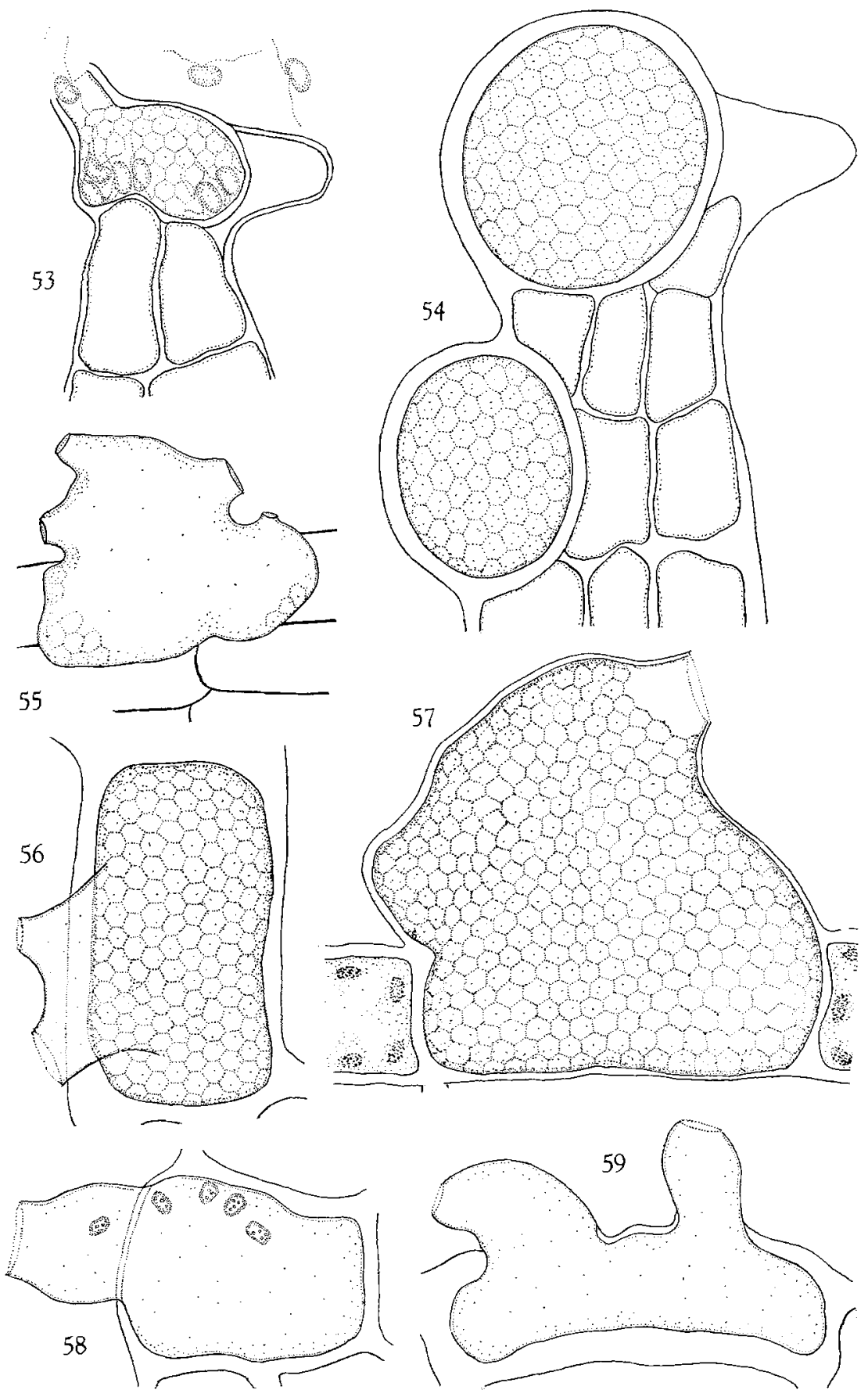

Figs. 53-59 
At maturity of the fungus parasitizing distal parts of the host, there were produced from the $15 \times 20 \mu$ to $50 \times 60 \mu$ thallus, $1-4$ discharge tubes $10-15 \mu$ in diameter which extruded from the host cell. All other parts of the parasite remained endobiotic, as in Olpidiopsis feldmanni Dixon (Figs. 53,54). Occasionally the thallus was somewhat lobed, but whether this was due, in fact, to multiple infection could not be determined. Zoospores were somewhat angular in the sporangium and upon emergence, singly, and free-swimming, were seen to be reniform in side view, $2 \times 4 \mu$, with two subapically attached, oppositely-directed flagella approximately 2-3 times the body in length (Fig. 53). They soon came to rest on the algal filament. It was evident after emergence of the swarmers that a very delicate reticulum was left behind in the sporangium (Figs. 53, 54). This suggested that the emerged zoospores were, indeed, secondary ones and had quitted the cysts of the primary stage. This would also account for their angularity before discharge.

The 1968 collections provided essentially the same picture except that no active zoospores were seen. Observations seemed to confirm that in young host cells the fungus remained confined except for discharge tubes, whereas in older parts in well-differentiated pericentral cells, a typical Eurychasma-like extrusion of the thallus took place (Fig. 55).

In Pterosiphonia fewer infections were seen and zoospore discharge was not observed although both completely empty sporangia and "net sporangia" were found (Figs. 56-59). Here, the fungus begins its development wholly endobiotically but there is soon extruded a broad extramatrical part (Figs. 57, 59) as in $E$. dicksonii. Seemingly, only mature pericentral cells were attacked.

It seems quite probable that only a single species of fungus is involved in both Polysiphonia apical cells and pericentral cells and in the pericentral cells of Pterosiphonia. The parasite is sufficiently well known now to warrant specific identity. In some features there is resemblance to Eurychasmidium tumaefaciens Sparrow (1936) also a parasite of red algae. The much fewer discharge tubes and encystment of zoospores within rather than outside the sporangium, however, ally it more closely with Eurychasma. The only report of Eurychasma on

Figs. 53-59. Eurychasma joycei n. sp. Figs. 53-55. In Polysiphonia sp. Figs. 56-59. In Pterosiphonia sp. Fig.53. Secondary biflagellate zoospores emerging from "net-sporangium" in parasitized apical cell of host. Fig.54. Apical and subapical cells with empty net-sporangia. Fig.55. Strongly emergent sporangium with 4 discharge tubes; in cortical host cell. Figs. 56, 57. Large empty "net-sporangia" in Pterosiphonia. Figs. 58, 59. Partially emerged sporangia. Evidently most of primary zoospores had emerged, without encystment. Figs. 53, 54, approx. $\times 825$ (by reproduction reduced to $1 / 2$ ). Fig. 55, approx. $\times 700$ (by reproduction reduced to $1 / 2$ ). Figs. $56-59, \times 825$ (by reproduction reduced to $1 / 2$ ) 
a red alga is that of the incompletely known Eurychasma sacculus H. E. Petersen (1905) on preserved Halosaccion and Rhodymenia from Greenland. Here, the endobiotic part, deep in the host, was strongly contorted and lobed and constricted as it passed through the superficial layer of the host. The epibiotic part was saccate with two short discharge tubes. No other characters were observed.

It does not seem likely that identical obligately parasitic fungi of this group would attack two such dissimilar hosts as Polysiphonia and the brown algae Ectocarpus, Striaria, etc. The red algal parasite is therefore considered a distinct species, named for its discoverer, E.joycei n. sp.

\section{Eurychasma joycei n. sp.}

Sporangium at maturity spherical to irregularly lobed generally confined within the apical and distal cells of the host, $15 \times 20 \mu$ to $50 \times 60 \mu$, when in mature pericentral cells protruding and saccate; with $1-4$ discharge tubes $10-15 \mu$ broad; secondary zoospores reniform $4 \mu$ long by $2 \mu$ broad, with 2 subapically attached, oppositely directed flagella 2-3 times length of body; primary zoospores for most part encysting within the sporangium, secondary ones emerging from the cysts and swimming out individually through the broad orifice of the discharge tubes, soon coming to rest; resting spore not observed.

Parasitic on apical and distal cells and more proximal pericentral cells of Polysiphonia sp. and pericentral cells of Pterosiphonia sp., "Marvista" San Juan Is., Wash. 8.19, 22.62, and 5.24.68, 8.6.68.

\section{Eurychasma joycei n. sp. ${ }^{1}$}

Sporangium maturum sphericum ad irregulariter lobatum, intra cellulas hospitis tumidas apicales distalesque, $15 \times 20 \mu-50 \times 60 \mu$ plerumque limitatum; in cellulis hospitis pericentralibus prominens et saccatum, $1-4$ tubulos dismissionis habens; zoosporae secondariae reniformes $4 \times 2 \mu$, duo flagella, sub apice affixa, ex adverso directa, $2-3$ plo longiora quam corpus, habentes; zoosporae primariae intra sporangium saepissime encystantes, zoosporae secondariae e cystibus primariis per 1-aliquot tubulos dimissionis latos emergentes, mox quiescentes; sporae quiescentes non observatae.

Plantae parasiticae in cellulis apicalibus distalibusque atque in cellula magis proximale pericentrali Polysiphoniae sp., et in cellulis pericentralibus Pterosiphoniae.

\section{Lagenidiaceae}

\section{Olpidiopsis sp.}

On Porphyra spp., on limestone cliff north of Limekiln Light, Haro Strait, 7.26 (coll. R. Norris).

The fungus has been recovered from a number of sites in the vicinity Friday Harbor by Dr. V. KRIShnamurThy who brought it to our

\footnotetext{
1 Translation kindly furnished by Dr. HannaH Croasdale.
} 
attention. Very young infections appear as light-green flecks on the red-brown thallus of the alga. Such spots when examined may show the cyst of the zoospore causing the infection as well as the young thallus within the discolored greenish cell (Fig. 47). Other cells in the vicinity without infection apparently may also lose their red pigments as though the infected area was exerting a lethal effect on surrounding cells (Fig. 48). The fungus spreads to other nearby cells producing new infections. Since the parasite thallus, which was ellipsoidal and 15 to $17 \times 12-13 \mu$ with a large central vacuole (Figs. 49, 50), is strictly non-mycelial and confined to a single cell new infections are by means of zoospores. In older infections the diseased area becomes considerably enlarged (Fig. 50) and the first-invaded part, now thoroughly disintegrated, falls out producing a "shot-hole" in the membranous host. Such shot-holes become more numerous as the fungus spreads by repeated zoospore infection. The zoospores are somewhat ellipsoidal, $5 \times 2.5 \mu$ with a minute droplet, and $6-10$ in a sporangium (Fig. 51). They were distinctly biflagellate, but were not seen in motion outside the sporangium. No resting stage was observed.

This is probably the biflagellate organism described by ARASAKI $(\mathbf{1 9 6 0} \mathrm{a}, \mathrm{b})$ from Japan as the cause of a serious "chytrid disease" of the economically important Porphyra sp. ("Nori"). There are, however, several minor differences between the two. The Japanese fungus caused some hypertrophy, had a more elongate discharge tube and zoospores with several droplets, not one. These are of questionable taxonomic significance, however. If resting spores had been observed in either species more could be said with certainty concerning relationships. Recently J. and G. FELdmanN (1967) have termed a somewhat similar fungus in Radicilingua reptans from the Mediterranean (?) Olpidiopsis dangeardii. There are points of difference from the Porphyra parasite.

An Olpidiopsis was also seen in cells of Antithamnion defectum (coll. G.J. HOLLENBBRG) which may be referable to $O$. feldmanni.

\section{Sirolpidiaceae}

Sirolpidium bryopsidis (de Bruyne) Pet.

In rhizoids of Cladophora sp.; same site as Porphyra parasite, 7.26 ; Bryopsis corticulum, same site, 7.26 .

The fungus in Cladophora was confined to the rhizoidal filaments. Very little infection of Bryopsis was found.

\section{E. Lagenidiaceae}

\section{Lagenidium sp.}

In filaments of Bryopsis corticulum, previous site and dates.

The fungus was readily cultured on modified Vishniac agar. Since no sex organs were produced it could not be identified as to species. 
The very elongate segments of the hyphae marked it, however, as a member of the Lagenidium oedogonii, etc., group.

\section{F. Olpidiaceae \\ Olpidium spp.}

Pine pollen, Friday Harbor, 7.6; salt pond off beach, north of American Camp, San Juan Is., 7.17.

Just which of the several described marine species of Olpidium was observed cannot be ascertained. The sporangia were $25 \mu$ in diameter with a very short, $8 \mu$ in diameter discharge tube (Fig. 52). A smoothwalled resting spore $15-20 \mu$ in diameter was associated with sporangial infections.

\section{G. Anisolpidiaceae}

\section{Anisolpidium rosenvingii (Petersen) Karling}

In Pylaiella sp., Fern Cove, Friday Harbor Laboratory; 6.8 (coll. Hollenberg). Very few stages were seen, but these were unmistakable.

\section{Literatur}

Arasaki, S.: A chytridean parasite on the Porphyra. Bull. Japanese Soc. Sci. Fisheries 26, 543-548 (1960a).

- The disease of cultured Porphyra. Bull. Japanese Soc. Sci. Fisheries 26, 1074 to 1081 (1960b).

Booth, T., and Charles E. Muller: Comparative morphologic and taxonomic studies in the genus Thraustochytrium. Mycologia (N.Y.) 60, 480-495 (1968).

Feldman,, J., et G.: Deux cas de Parasitisme sur des Algues marines. Travaux de Biologie végétale dédiés au Professor Pierre Dangeard. La Botaniste 50, $185-203$ (1967).

Fuller, M. S., Bruce E. Fowlfes, and D. J. Molaughuin: Isolation and pure culture study of marine phycomycetes. Mycologia (N.Y.) 66, 745-756 (1964).

GaERTNER, A.: Eine Methode des quantitativen Nachweises niederer, mit Pollen köderbarer Pilze im Meerwasser und im Sediment. Veröff. Inst. Meeresforsch. Bremerhaven, Sonderband 3, S. 75-92.

Johrson, T.W., JR.: A Lagenidium in the marine diatom Coscinodiscus centralis. Mycologia (N.Y.) 58, 131-135 (1966).

Petersen, H. E.: Contributions à la connaissance des Phycomycètes marins (Chytridineae Fischer). Oversigt Kgl. Danske Vidensk. Selskabs. Forhandl., 1905 (5), 439-488 (1905).

Schnemder, J.: Ein neuer mariner Phycomycet aus der Kieler Bucht (Thraustochytrium striatum spec. nov.). Kieler Meeresforsch. 23, 16-20 (1968).

Sparrow, F. K. : Biological observations on the marine fungi of Woods Hole waters. Biol. Bull. 70, 236-263 (1936).

- On the occurrence of the Thraustochytriaceae. Veröff. Inst. Meeresforsch. Bremerhaven 11, 89-92 (1968).

Ulken, A.: Zwei neue Thraustochytrien aus der Außenweser. Veröff. Inst. Meeresforsch. Bremerhaven 9, 289-295 (1965).

Vishniad, H. S.: On the ecology of the lower marine fungi. Biol. Bull. 111, 410-414 (1956).

Professor Dr. F. K. Spariow

The University of Michigan, Department of Botany Ann Arbor, Michigan 48104, U.S.A. 